Supporting Information to accompany:

\title{
A Stable Organo-Aluminum Analyte Enables Multi-Electron Storage for a Nonaqueous Redox Flow Battery
}

Amela Arnold, Ryan J. Dougherty, Cody R. Carr, Lauren C. Reynolds, James C. Fettinger, Anthony Augustin, and Louise A. Berben*

Department of Chemistry, University of California, Davis CA 95616

email: laberben@ucdavis.edu 


\section{Table of Contents}

1. Experimental Methods

2. Extended cycling methods and Calculations

Calculation S1. Energy density $(\hat{E})$ calculation.

Calculation S2. Randles-Sevcik equation to estimate the diffusion coefficients.

Calculation S3. Heterogenous electron-transfer rate constants calculation.

Calculation S4. Determination of 70\% state of charge (SOC).

3. Tables and Charts

Table S1. Crystallographic data for $\mathbf{2 b}$.

Chart S1. Numbering scheme for $\mathbf{2 b}$ for Table S2.

Table S2. Selected average interatomic distances and selected average angles for $\mathbf{2 b}$.

4. Figures

Figure S1. Solid state structure of $\mathbf{2 b}$.

Figure S2. UV-Vis spectra of complexes 1, 2a, 2b, and $\mathbf{3}$.

Figure S3. Cyclic voltammetry data to test the reversibility of redox couples of $\mathbf{2 b}$. Plots of current density $\left(j_{\mathrm{p}}\right)$ vs the square root of the scan rate $\left(v^{1 / 2}\right)$. Plots of the inverse of the square root of scan rate $\left(v^{-1 / 2}\right)$ versus the transfer parameter $(\psi)$, extracted from the peak to peak separation $\left(\Delta E_{\mathrm{p}}\right)$ between each redox couple at varying scan rates.

Figure S4. CV's of analyte solution in working side compartment before and after extended cycling (charging/discharging or C/D) experiments using glassy carbon (GC) plate, 100 PPI reticulated vitreous carbon, and graphite electrodes.

Figure S5. Extended cycling experiment using carbon felt as the working and counter electrode.

Figure S6. CV's of $\mathbf{2 b}$ at varied concentrations in $0.5 \mathrm{MnBu}_{4} \mathrm{NBF}_{4} \mathrm{MeCN}$.

Figure S7. Crossover of analyte $\mathbf{2 b}$ over time.

Figure S8. CV's of working and counter compartments after $73 \mathrm{~h}$ and $450 \mathrm{~h}$ of charging and discharging of $\mathbf{2 b}$ in a symmetric $\mathrm{H}$-cell using a glass frit separator.

Figure S9. C/D experiment with $\mathbf{2 b}$ using a fine glass frit separator in a symmetric H-cell over $450 \mathrm{~h}$.

Figure S10. Voltaic, coulombic and overall energy efficiency over the first $25 \mathrm{C} / \mathrm{D}$ cycles of $\mathbf{2 b}$ in a symmetric H-cell separated by a fine glass frit.

Figure S11. Coulombic efficiency of $100 \mathrm{C} / \mathrm{D}$ cycles, and CV's before and after of $\mathbf{2 b}$ using anion-exchange membrane separator.

Figure S12. Extended cycling of $\mathbf{2 b}$ using an anion-exchange membrane separator.

Figure S13. Extended cycling of $\mathbf{2 b}$ as an anolyte for an asymmetric battery cell using an anion-exchange membrane separator; CV's of working compartment of asymmetric H-cell battery, after 10 cycles; Coulombic efficiency of each cycle.

Figure S14. CD and CV's of asymmetric H-cell battery with glass frit separator.

Figure S15. Coulombic efficiency of each $\mathrm{C} / \mathrm{D}$ cycle with asymmetric H-cell battery with glass frit separator, with $V_{\text {cell }}=1.6 \mathrm{~V}, V_{\text {cell }}=1.9 \mathrm{~V}$ and $V_{\text {cell }}=2.1 \mathrm{~V}$.

Figure S16. Photo of $\mathrm{H}-\mathrm{Cell}$ with anion-exchange membrane separator.

Figure S17. Photo of H-Cell with glass frit separator. 


\section{References}

\section{Experimental Methods}

Electrochemical Measurements. Charge-discharge studies were performed inside of a glovebox under an inert atmosphere using a CH Instruments Electrochemical Analyzer Model 1400. The custom Hcell was designed by Adams and Chittenden (Figure S21 and S22) with compartments separated by an AMI-7001S Anion exchange membrane (Membrane International Inc.) or glass frit. If a membrane was used, it was soaked in $0.5 \mathrm{MnBu}_{4} \mathrm{NBF}_{4} \mathrm{MeCN}$ electrolyte solution for $48 \mathrm{~h}$ prior to use. The working compartment was fit with an $\mathrm{Ag} / \mathrm{AgNO}_{3}$ reference electrode, isomolded graphite rod (Graphite Store) working electrode and $7.5 \mathrm{mM}$ of the complex in $3.5 \mathrm{~mL} 0.5 \mathrm{M} \mathrm{nBu}_{4} \mathrm{NBF}_{4} \mathrm{MeCN}$ electrolyte solution. In the asymmetric studies, the counter compartment contained only $3.5 \mathrm{~mL} 0.5 \mathrm{M} \mathrm{nBu} \mathrm{NBF}_{4} \mathrm{MeCN}$ electrolyte solution, and an isomolded graphite rod counter electrode. For the studies with a symmetric NRFB configuration, the first cycle was a galvanostatic charging of a concentrated solution of $\mathbf{2} \mathbf{b}$ to $\mathbf{2} \mathbf{b}^{-}$;

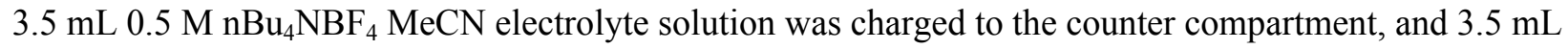
$15 \mathrm{mM} 2 \mathbf{b}$ in $0.5 \mathrm{M} \mathrm{nBu}_{4} \mathrm{NBF}_{4} \mathrm{MeCN}$ electrolyte solution was charged to the working compartment. A 0.2 $\mathrm{mA}$ current was applied to the working compartment until a potential cut-off of $-0.6 \mathrm{~V}$ was reached (approximately 2 hours). The electrolyte solution in the counter compartment was then discarded and 1.75 $\mathrm{mL}$ of the $15 \mathrm{mM} \mathbf{2} \mathbf{b}^{-}$was charged to the counter compartment and both compartments were diluted to reach $3.5 \mathrm{~mL}$ of $7.5 \mathrm{mM} \mathbf{2} \mathbf{b}^{-}$. In both symmetric and asymmetric studies, a stirring rate of $900 \mathrm{RPM}$ was found to be optimal for C/D studies, voltage cut-offs were employed to achieve a calculated 70\% state-ofcharge (SOC) in each experiment. The SOC was not independently verified. Between experiments, the electrodes were soaked and sonicated with $1 \mathrm{M} \mathrm{HCl}$, followed by distilled water twice, then acetone. They were then dried at $100 \mathrm{C}$ for two hours prior to use.

Cyclic voltammograms (CVs) were recorded in a nitrogen-filled glovebox with a $\mathrm{CH}$ Instruments Electrochemical Analyzer Model 620D or 1400 with a glassy carbon working electrode (CH Instruments, nominal surface area of $\left.0.071 \mathrm{~cm}^{2}\right)$, a platinum wire auxiliary electrode, and an $\mathrm{Ag} / \mathrm{AgNO}_{3}(0.001 \mathrm{M})$ nonaqueous reference electrode with a Vycor tip. All potentials are referenced to the SCE couple, and ferrocene was used as an external standard where the $E_{1 / 2}$ of ferrocene/ferrocenium is $+0.40 \mathrm{~V}$ vs. SCE in $0.1 \mathrm{M}$ $\mathrm{Bu}_{4} \mathrm{NPF}_{6} \mathrm{MeCN}^{1} \mathrm{Bu}_{4} \mathrm{NPF}_{6}$ was recrystallized from ethanol and placed under vacuum for 72 hours before electrolyte solutions were made. Electrolyte solutions were stored over $3 \AA$ molecular sieves for at least 48 hours before use. Sieves were activated by heating under vacuum at $270^{\circ} \mathrm{C}$ for at least 72 hours. UV-Vis spectra were obtained using a $1 \mathrm{~cm}$ cuvette using an Agilent $8453 \mathrm{UV}$-vis spectrophotometer.

X-ray Structure determinations. X-ray diffraction studies were carried out on a Bruker SMART APEXII, and a Bruker Photon100 CMOS diffractometer equipped with a CCD detector. ${ }^{2 a}$ Measurements were carried out at $90 \mathrm{~K}$ using $\mathrm{Mo} \mathrm{K} \alpha(\lambda=0.71073 \AA)$ and $\mathrm{Cu} \mathrm{K} \alpha(1.5418 \AA)$ radiation. Crystals were mounted on a Kaptan Loop with Paratone- $N$ oil. Initial lattice parameters were obtained from a least-squares analysis of more than 100 centered reflections; these parameters were later refined against all data. Data was integrated and corrected for Lorentz polarization effects using SAINT ${ }^{3 b}$ and were corrected for absorption effects using SADABS2.3. ${ }^{3 \mathrm{c}}$

Space group assignments were based upon systematic absences, $E$ statistics, and successful refinement of the structures. Structures were solved by direct methods with the aid of successive difference Fourier maps and were refined against all data using the SHELXTL 5.0 software package. ${ }^{1 \mathrm{~d}}$ Thermal parameters for all non-hydrogen atoms were refined anisotropically. Hydrogen atoms, where added, were assigned to ideal positions and refined using a riding model with an isotropic thermal parameter 1.2 times that of the attached carbon atom (1.5 times for methyl hydrogens). 
Other Physical Measurements. ${ }^{1} \mathrm{H}$ NMR spectra were recorded at ambient temperature using a Varian $600 \mathrm{MHz}$ spectrometer. Chemical shifts were referenced to residual solvent. Elemental analyses were performed by the Microanalytical Laboratory at University of California Berkeley.

Solubility studies of $1,2 a, 2 b$ and 3. Stock solutions of each complex were prepared in acetonitrile. These were then diluted in $10 \mathrm{~mL}$ volumetric flasks to prepare four standard solutions. The absorbance of these four solutions were obtained and a suitable wavelength was chosen for a calibration curve of absorbance versus concentration. Saturated solutions were obtained by stirring excess complex in $400-500 \mu \mathrm{L}$ of $\mathrm{MeCN}$ in a $20 \mathrm{~mL}$ vial. The solution was then filtered through a kimwipe pipette filter to remove undissolved material, and the saturated solution was then diluted in order for absorbances to fall within the absorption range of the calibration curve (Figure S6).

Preparation of Compounds. All manipulations were carried out using standard Schlenk or glovebox techniques under a dinitrogen atmosphere. Unless otherwise noted, solvents were deoxygenated and dried by thorough sparging with Ar gas followed by passage through an activated alumina column. Deuterated solvents were purchased from Cambridge Isotopes Laboratories, Inc. and were degassed and stored over activated $3 \AA$ molecular sieves prior to use. Bis(imino)pyridine $\left(\mathrm{I}_{2} \mathrm{P}\right),{ }^{3} \mathbf{1}, \mathbf{2} \mathbf{a}$, and $\mathbf{3},{ }^{3}$ were synthesized according to the literature. Other reagents were purchased from commercial vendors and used without further purification.

[( $\left.\left.\mathbf{I}_{2} \mathbf{P}^{-}\right)_{2} \mathbf{A l}\right][\mathbf{O T f}]$ (2b). Solid sodium (2.0 equiv., $0.603 \mathrm{mmol}, 14.1 \mathrm{mg}$ ) was added to two equivalents of the $\mathrm{I}_{2} \mathrm{P}(300 \mathrm{mg}, 0.603 \mathrm{mmol})$ dissolved in THF $(10 \mathrm{~mL})$. After stirring for $16 \mathrm{~h}$, the solution was a dark green-brown color. One equivalent of $\mathrm{AlCl}_{3}(0.302 \mathrm{mmol}, 40.2 \mathrm{mg})$ dissolved in THF ( $\left.3 \mathrm{~mL}\right)$ was added, resulting in a color change to a bright red solution which was stirred for one hour. Potassium trifluoromethanesulfonate (1.1 equiv., $0.333 \mathrm{mmol}, 62.6 \mathrm{mg}$ ) dissolved in THF $(2 \mathrm{~mL})$ was added. After stirring overnight, the solution was removed in vacuo. Benzene $(2 \times 10 \mathrm{~mL})$ was stirred with the oily solid for $1 \mathrm{~h}$ and then the mixture was filtered through celite and the celite pad was washed with fresh benzene. The benzene-insoluble oily solids were dissolved in acetonitrile $(10 \mathrm{~mL})$, filtered through the same celite pad and then concentrated to a red powder $(254 \mathrm{mg}, 73 \%)$. Single crystals suitable for X-ray diffraction were grown from a concentrated benzene solution over $16 \mathrm{~h}$ at room temperature. Anal. Calcd. for $\mathrm{C}_{67} \mathrm{H}_{54} \mathrm{AlF}_{3} \mathrm{~N}_{6} \mathrm{O}_{7} \mathrm{~S} \cdot 3 \mathrm{H}_{2} \mathrm{O}: \mathrm{C}, 65.68 ; \mathrm{H}, 4.94 ; \mathrm{N}, 6.86$. Found: $\mathrm{C}, 65.92 ; \mathrm{H}, 4.88 ; \mathrm{N}, 6.58$. UV-Vis spectrum $(\mathrm{MeCN}) \lambda_{\max }\left(\varepsilon_{\mathrm{M}}\right): 266$ (25 600), 347 (16 700), 463 (br, 10200$) \mathrm{nm}\left(\mathrm{L} \mathrm{mol}^{-1} \mathrm{~cm}^{-1}\right) \cdot \mu_{\mathrm{eff}}=2.3 \mu_{\mathrm{B}}$.

\section{Calculations}

Calculation S1. Energy density $(\hat{E})$ calculation.

The energy density $(\hat{E})$ of a RFB is affected by the electrochemical properties given by equation $\mathrm{S} 1$.

$$
\hat{\mathrm{E}}=0.5 n V_{\text {cell }} C_{\text {active }} F \quad \text { (equation } \mathrm{S} 1 \text { ) }
$$

Where $n$ is the number of electrons transferred, $V_{\text {cell }}$ is the electrochemical stability window, $C_{\text {active }}$ is the concentration of the electro-active analyte and $F$ is Faraday's constant $\left(96.485 \mathrm{~kJ} \mathrm{~V} \mathrm{~mol}^{-1}\right)$. Note: This equation is valid for cells that contain anolytes and catholytes that transfer the same number of electrons and at the same concentration. Although even when this is not true the energy density will still scale with $V_{\text {cell }}$ and $C_{\text {active. }}$

Calculation S2. Randles-Sevcik equation to calculation diffusion coefficients $\left(D_{0}\right)$. 
The diffusion coefficients for each redox couple were determined by first plotting CV's of $\mathbf{2 b}$ at varying scan rates $(0.2-8 \mathrm{~V} / \mathrm{s})$ (Figure $\mathrm{S} 7)$. The diffusion coefficients were then determined from the slope of the peak current density $\left(j_{\mathrm{p}}\right)$ versus the square root of the scan rate $\left(v^{1 / 2}\right)$ :

$$
j_{p}=268600 n_{e}^{3 / 2} D_{0}^{1 / 2} C_{0} v^{1 / 2} \quad \text { (equation S2) }
$$

where $j_{\mathrm{p}}$ is the current density in $\mathrm{A} / \mathrm{cm}^{2}, n_{\mathrm{e}}$ is the number of electrons (here $n_{\mathrm{e}}=1$ ), $D_{0}$ is the diffusion coefficient $\left(\mathrm{cm}^{2} / \mathrm{s}\right), C_{0}$ is the bulk concentration $(\mathrm{mol} / \mathrm{mL})$ and $v$ is the scan rate $(\mathrm{V} / \mathrm{s})$. Straight lines fit to these plots indicate that the electron transfer events can be considered reversible.

Calculation S3. Calculation of heterogenous electron-transfer rate constant $\left(k_{0}\right)$ using the Nicholson method.

Using equation S2, transfer parameter $(\psi)$ was calculated by obtaining the peak to peak separation of each redox couple $\left(\Delta E_{\mathrm{p}}\right)$, at varying scan rates $(0.2-8 \mathrm{~V} / \mathrm{s})$ (Figure $\left.\mathrm{S} 7\right):^{4}$

$$
\psi=\frac{\left(-0.6288+0.0021 \Delta E_{p}\right)}{1-0.017 \Delta E_{p}} \quad \text { (equation S3) }
$$

The electron transfer rate constant $\left(k_{0}\right)$ was then extracted from the slope of a plot of $\psi$ versus $v^{-1 / 2}$ (Figure S7):

$$
\psi=\frac{k_{0}}{\left(\frac{\pi n F D v}{R T}\right)^{\frac{1}{2}}} \quad \text { (equation S4) }
$$

Where $n$ is the number of electrons transferred, $F$ is the Faraday constant $\left(96485 \mathrm{Cmol}^{-1)}, D\right.$ is the averaged diffusion coefficient for the oxidation and reduction reaction $\left(D_{\mathrm{O}}\right.$ and $\left.D_{\mathrm{R}}\right)\left(\mathrm{cm}^{2} / \mathrm{s}\right), v$ is the scan rate $(\mathrm{V} / \mathrm{s}), \mathrm{R}$ is the ideal gas constant $(8.314 \mathrm{~J} / \mathrm{mol} \cdot \mathrm{K})$ and $\mathrm{T}$ is the temperature $(\mathrm{K})$.

Calculation S4. Determination of $70 \%$ state of charge (SOC).

Theoretical capacity of the cell $=0.0215 \mathrm{mmol} \times 96,485.33 \mathrm{sA} / \mathrm{mol}=2.07 \mathrm{sA}=0.576 \mathrm{mAh}$ $70 \%$ state of charge $=0.403 \mathrm{mAh}$

Galvanostatic charging current for $2 \mathrm{~h}$ at $70 \% \mathrm{SOC}: 0.403 \mathrm{mAh} / 2 \mathrm{~h}=0.201 \mathrm{~mA}$

Galvanostatic discharging current for $2 \mathrm{~h}$ at $70 \%$ SOC: $0.403 \mathrm{mAh} / 2 \mathrm{~h}=0.201 \mathrm{~mA}$. 


\section{Tables}

Table S1. Crystallographic data ${ }^{a}$ for $\left[\left(\mathrm{I}_{2} \mathrm{P}^{-}\right)_{2} \mathrm{Al}\right][\mathrm{OTf}](\mathbf{2 b})$.

\begin{tabular}{|c|c|}
\hline & $2 \mathbf{b}$ \\
\hline Formula & $\begin{array}{c}\mathrm{C}_{66} \mathrm{H}_{54} \mathrm{AlF}_{3} \mathrm{~N}_{6} \mathrm{O}_{7} \mathrm{~S} \\
\cdot 2.5 \mathrm{C}_{6} \mathrm{H}_{6}\end{array}$ \\
\hline Crystal size $\left(\mathrm{mm}^{3}\right)$ & $0.583 \times 0.321 \times 0.126$ \\
\hline Formula wt, $\mathrm{g} \mathrm{mol}^{-1}$ & 1366.47 \\
\hline Space group & $P \overline{1}$ \\
\hline$a, \AA$ & $17.9238(5)$ \\
\hline$b, \AA$ & $18.2762(6)$ \\
\hline$c, \AA$ & $25.2916(8)$ \\
\hline$\alpha, \operatorname{deg}$ & $92.1328(18)$ \\
\hline$\beta$, deg & $102.0076(17)$ \\
\hline$\gamma, \operatorname{deg}$ & $115.9687(18)$ \\
\hline$V, \AA^{3}$ & $7207.5(4)$ \\
\hline$Z$ & 4 \\
\hline$T, \mathrm{~K}$ & $100(2)$ \\
\hline$\rho$, calcd. $\mathrm{gcm}^{-3}$ & 1.259 \\
\hline Refl. collected $/ 2 \theta_{\max }$ & $48405 / 137.93$ \\
\hline Unique refl./ $I>2 \sigma(I)$ & $26358 / 21155$ \\
\hline No. parameters/restraints & $1930 / 133$ \\
\hline$\lambda, \AA / \mu(\mathrm{K} \alpha), \mathrm{cm}^{-1}$ & 1.54178 \\
\hline $\mathrm{R}_{1} / \mathrm{GOF}$ & $0.0766 / 1.047$ \\
\hline $\mathrm{wR}_{2}(I>2 \sigma(I))$ & 0.1818 \\
\hline Residual density, $\mathrm{e} \AA^{-3}$ & $0.679 /-0.467$ \\
\hline
\end{tabular}

${ }^{a}$ Obtained with graphite-monochromated $\mathrm{Cu} \mathrm{K} \alpha(\lambda=1.54178 \AA)$ radiation. ${ }^{b} R_{1}=\Sigma|| F \mathrm{o}|-F \mathrm{c}||\Sigma| F \mathrm{o} \mid, \mathrm{w} R_{2}=\left\{\Sigma\left[\mathrm{w}\left(F_{\mathrm{o}^{2}-}\right.\right.\right.$ $\left.\left.\left.F \mathrm{c}^{2}\right)^{2}\right] / \Sigma\left[\mathrm{w}\left(F \mathrm{o}^{2}\right)^{2}\right]\right\}^{1 / 2}$.

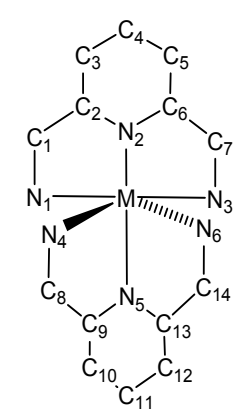

Chart S1. Numbering scheme for $\mathbf{2 b}$ for Table S2. 
Table S2. Selected average interatomic distances $(\AA)$ and selected average angles (deg) for the complexes in $\left[\left(\mathrm{I}_{2} \mathrm{P}^{-}\right)_{2} \mathrm{Al}\right][\mathrm{OTf}](\mathbf{2 b})$.

\begin{tabular}{lcc}
\hline & $\mathbf{2 b}$ & $\mathbf{2 b}$ \\
\hline $\mathrm{Al}-\mathrm{N}_{1}$ & $2.056(3)$ & $2.065(3)$ \\
$\mathrm{Al}-\mathrm{N}_{2}$ & $1.890(2)$ & $1.894(2)$ \\
$\mathrm{Al}-\mathrm{N}_{3}$ & $2.076(3)$ & $2.024(3)$ \\
$\mathrm{Al}-\mathrm{N}_{4}$ & $2.059(2)$ & $2.022(3)$ \\
$\mathrm{Al}-\mathrm{N}_{5}$ & $1.891(2)$ & $1.900(3)$ \\
$\mathrm{Al}-\mathrm{N}_{6}$ & $2.048(2)$ & $2.070(4)$ \\
$\mathrm{N}_{1}-\mathrm{C}_{1}$ & $1.329(4)$ & $1.308(4)$ \\
$\mathrm{N}_{3}-\mathrm{C}_{7}$ & $1.314(4)$ & $1.335(3)$ \\
$\mathrm{N}_{4}-\mathrm{C}_{8}$ & $1.316(4)$ & $1.331(4)$ \\
$\mathrm{N}_{6}-\mathrm{C}_{14}$ & $1.317(3)$ & $1.308(4)$ \\
$\mathrm{C}_{1}-\mathrm{C}_{2}$ & $1.439(5)$ & $1.453(4)$ \\
$\mathrm{C}_{7}-\mathrm{C}_{6}$ & $1.457(5)$ & $1.452(5)$ \\
$\mathrm{C}_{8}-\mathrm{C}_{9}$ & $1.443(4)$ & $1.443(5)$ \\
$\mathrm{C}_{14}-\mathrm{C}_{13}$ & $1.443(4)$ & $1.466(5)$ \\
$\mathrm{N}_{1}-\mathrm{Al}-\mathrm{N}_{3}$ & $157.7(1)$ & $158.2(1)$ \\
$\mathrm{N}_{4}-\mathrm{Al}-\mathrm{N}_{6}$ & $157.7(1)$ & $158.1(1)$ \\
$\mathrm{N}_{2}-\mathrm{Al}-\mathrm{N}_{5}$ & $177.0(1)$ & $175.7(1)$ \\
\hline
\end{tabular}

\section{Figures}

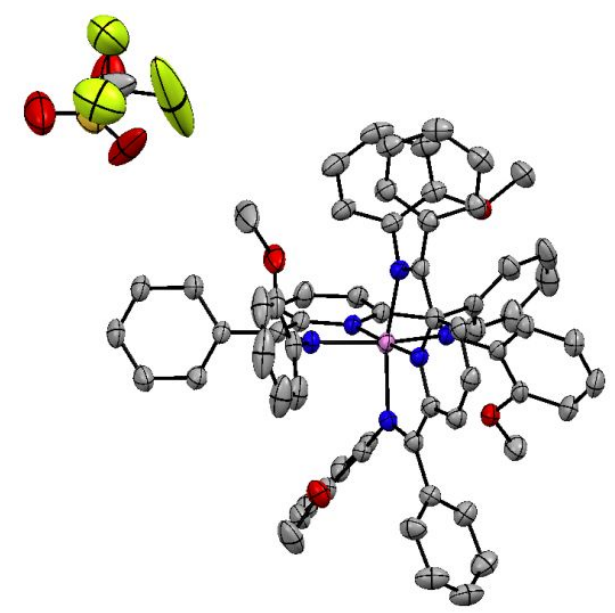

Figure S1. Solid state structure of $\mathbf{2 b}$. Grey, blue, red, pink, orange, and yellow ellipsoids represent $\mathrm{C}, \mathrm{N}, \mathrm{O}, \mathrm{Al}, \mathrm{S}$, and $\mathrm{F}$ atoms, respectively. Solvent molecules and $\mathrm{H}$ atoms have been removed for clarity. Ellipsoids shown at 50\%. 

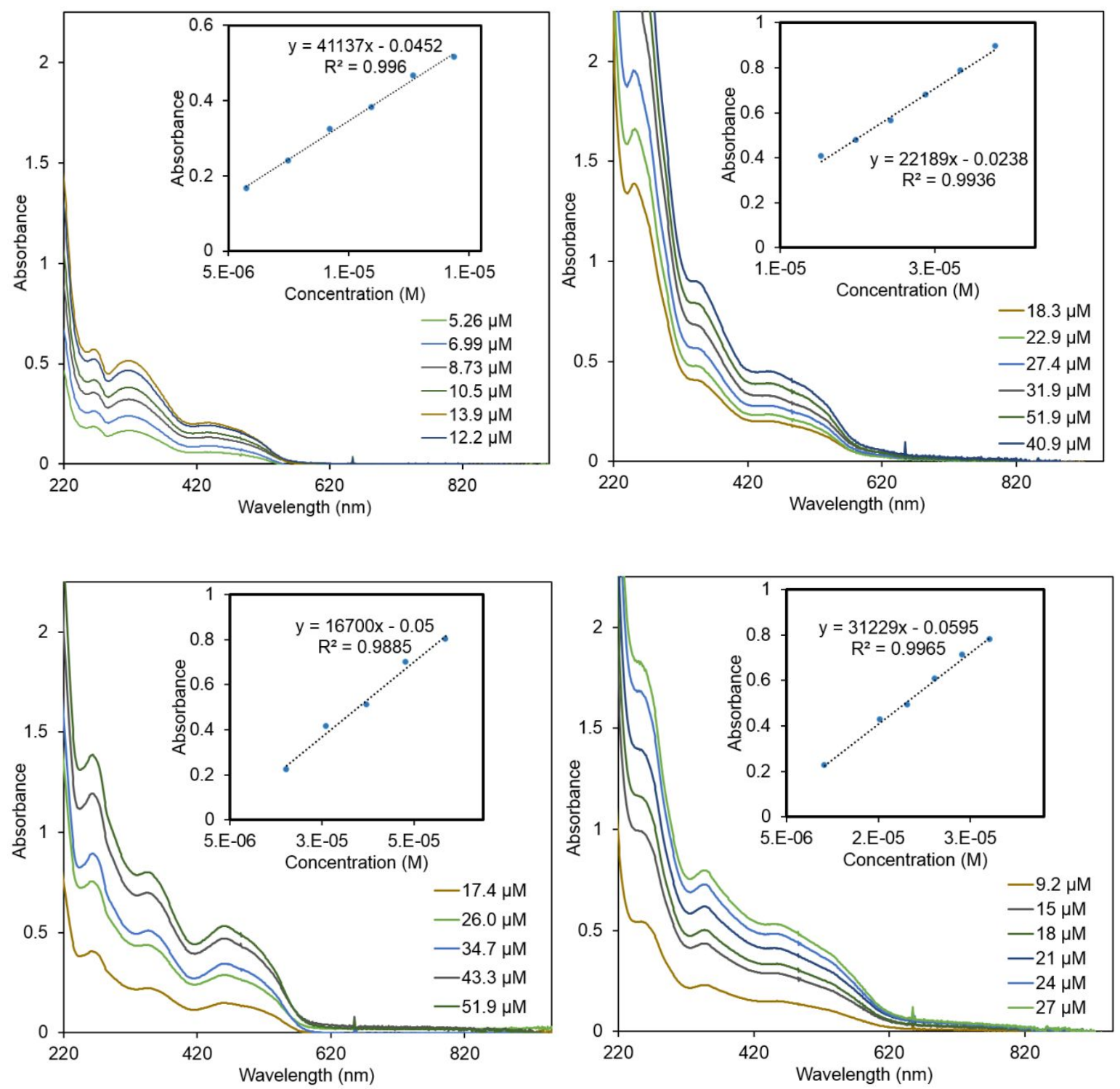

Figure S2. UV-Vis spectra of complex 1, 2a, 2b, and $\mathbf{3}$ at various concentrations $\left(\mathrm{MeCN}, 25^{\circ} \mathrm{C}\right)$. Inset: Calibration curve of absorbance at $318,347,347$ and $355 \mathrm{~nm}$ as a function of concentration in $\mathrm{MeCN}$ at $25^{\circ} \mathrm{C}$. 

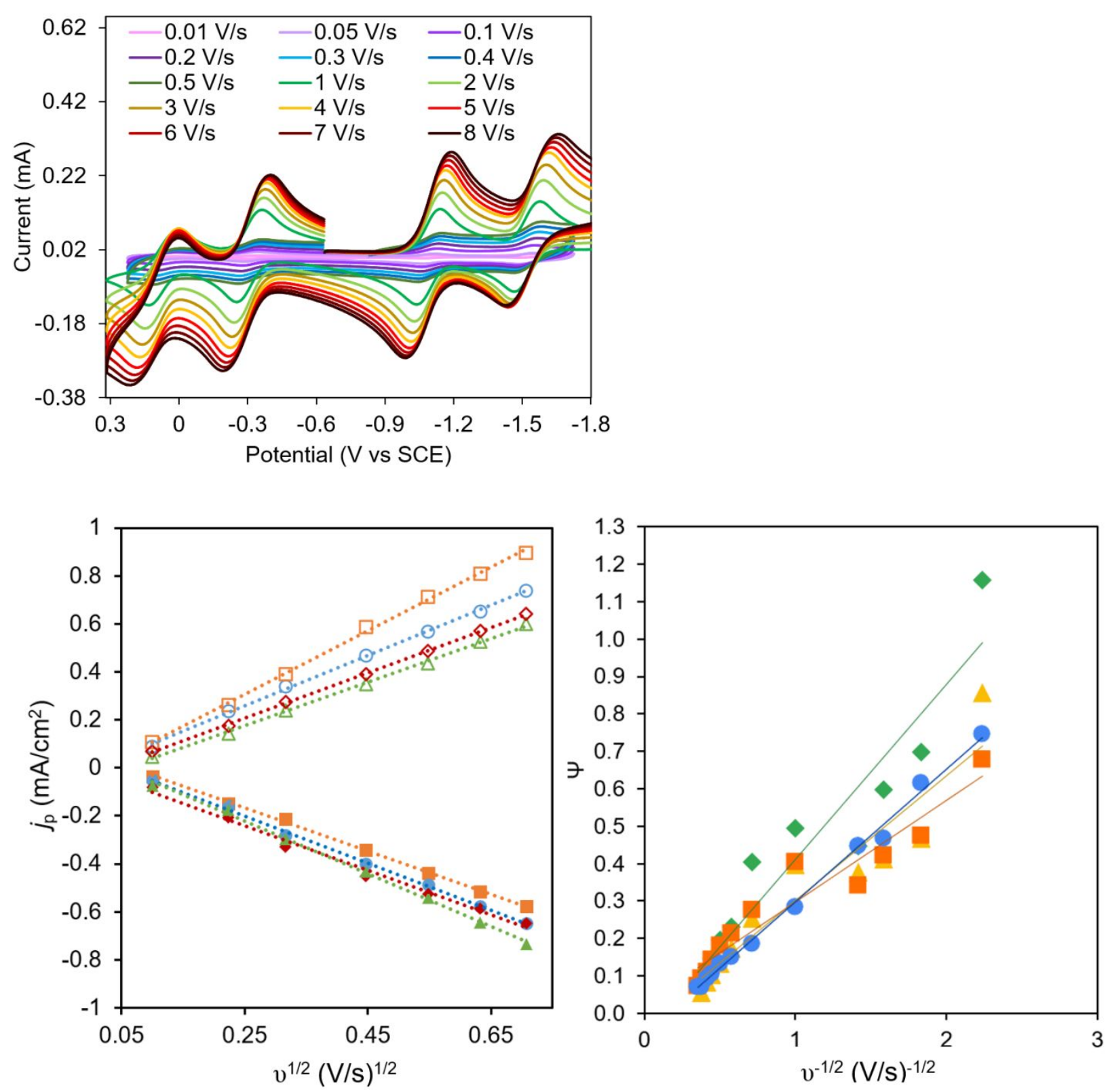

Figure S3. (top) Cyclic voltammetry data to test the reversibility of redox couples of $\mathbf{2 b}(1 \mathrm{mM})$. Scan rates range from 0.01 to $8 \mathrm{~V} / \mathrm{s}$ in $0.1 \mathrm{M} \mathrm{Bu}_{4} \mathrm{NBF}_{4} \mathrm{MeCN}$. (left bottom) Plots of current density $\left(j_{\mathrm{p}}\right)$ vs the square root of the scan rate $\left(v^{1 / 2}\right)$ were extracted from the linear portion of the data $0.01-0.5 \mathrm{~V} / \mathrm{s}$. (right bottom) Plots of the inverse of the square root of scan rate $\left(v^{-1 / 2}\right)$ versus the transfer parameter $(\psi)$, extracted from the peak to peak separation $\left(\Delta E_{\mathrm{p}}\right)$ between each redox couple at varying scan rates, according to equation S2. 

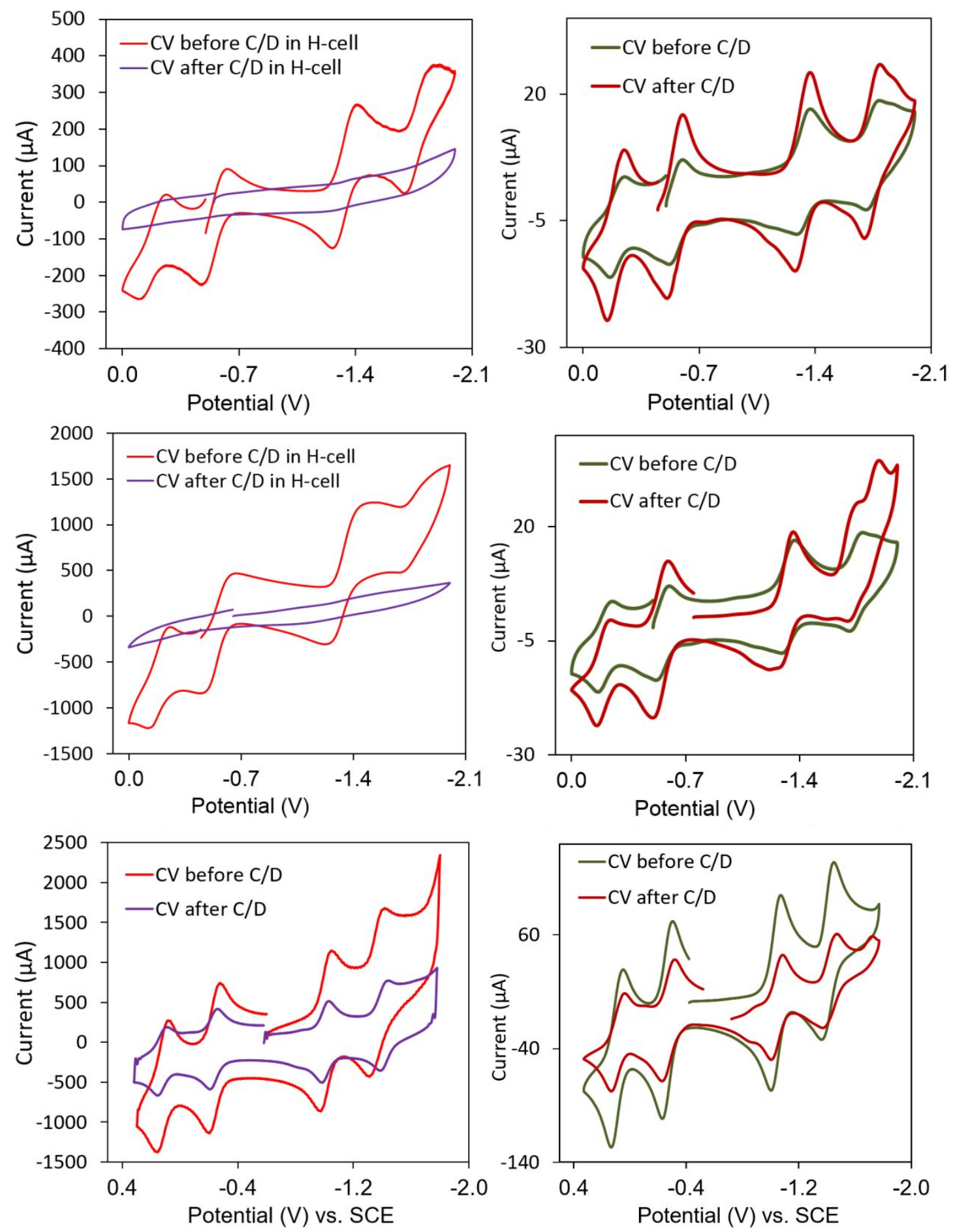

Figure S4. CV's of analyte solution in working side compartment before and after extended cycling (charging/discharging or C/D) experiments using various electrodes for both the working and counter electrode: (top) glassy carbon (GC) plate, (middle) 100 PPI reticulated vitreous carbon, and (bottom) graphite electrode.

CV's were obtained in the H-cell using (left) the electrode used in $\mathrm{C} / \mathrm{D}$ as the working and counter electrode before, red; and after, purple C/D; (right) CV's were also obtained using a fresh GC button electrode before, green; and after, red C/D. All CV's are referenced to SCE. 


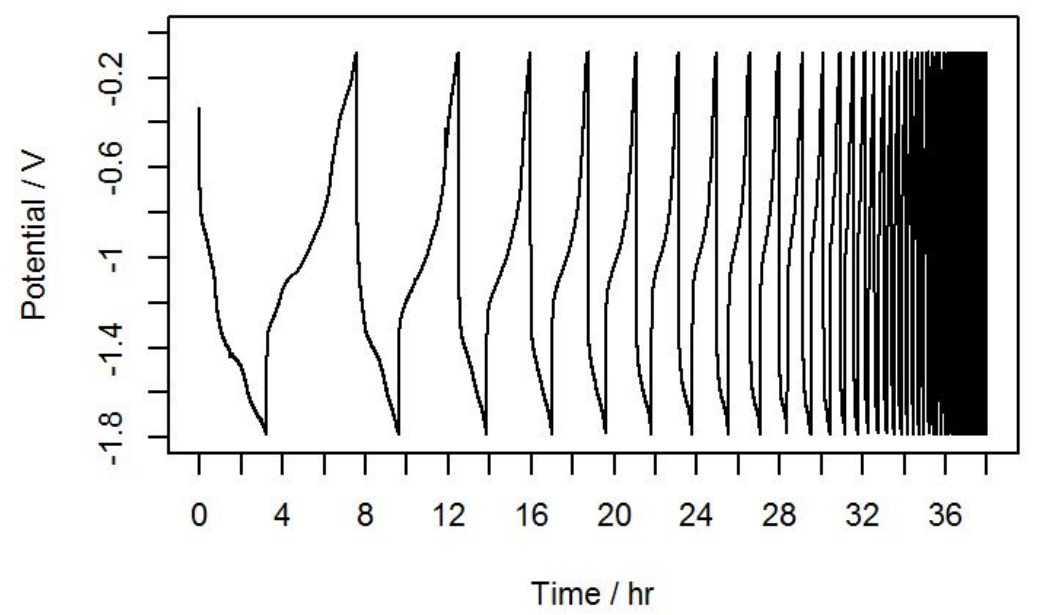

Figure S5. Extended cycling experiment using carbon felt as the working and counter electrode: no clear features/plateaus were observed.
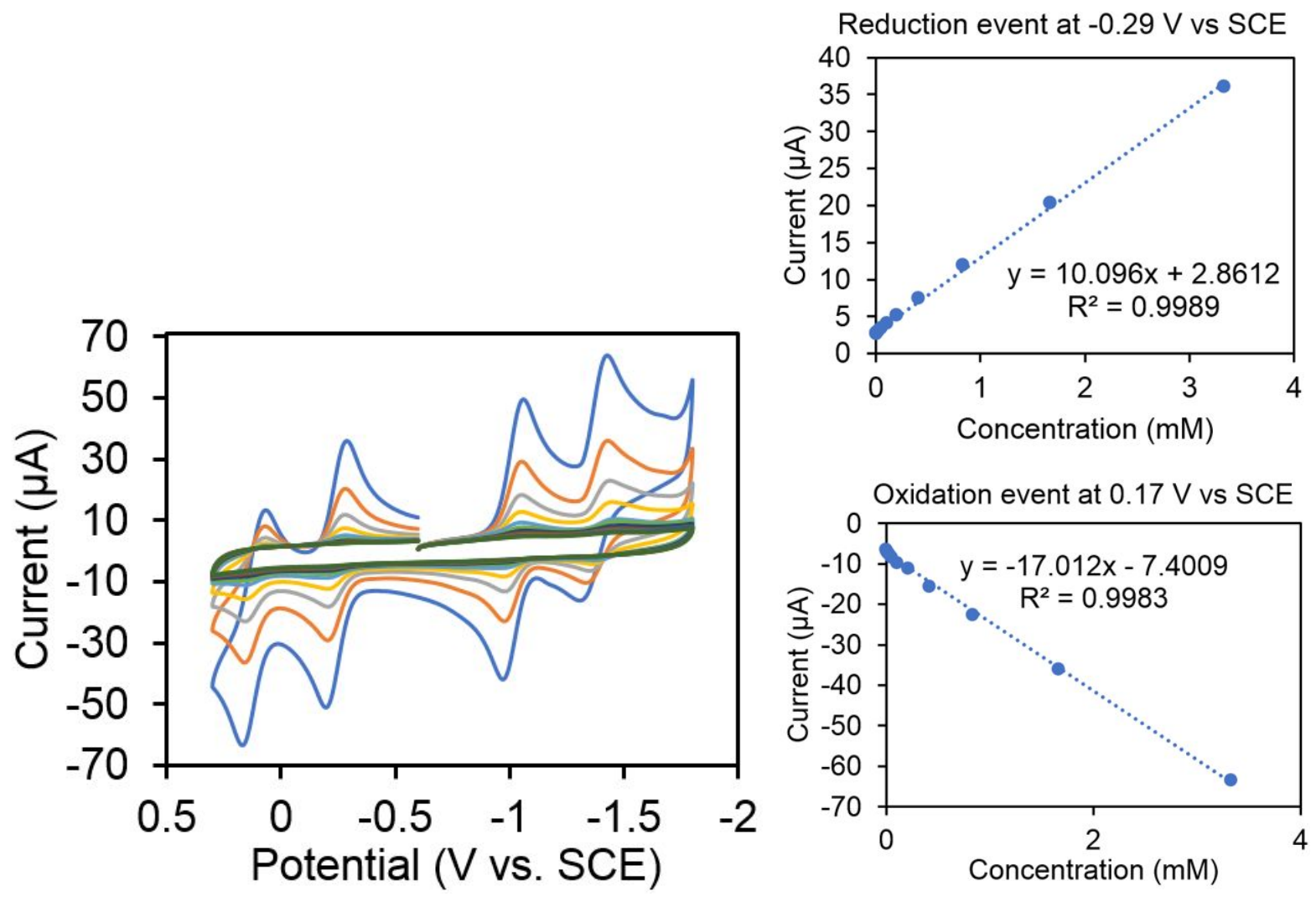

Figure S6. (left) CV's of $\mathbf{2 b}$ at varied concentrations in $0.5 \mathrm{M} \mathrm{nBu}_{4} \mathrm{NBF}_{4} \mathrm{MeCN}$. Glassy carbon working electrode, $\mathrm{Pt}$ wire counter electrode, $\mathrm{Ag} / \mathrm{AgNO}_{3}$ reference electrode. (right) Calibration curve of concentration vs current for the reduction event at $-0.29 \mathrm{~V}$ (top) and the oxidation event at $0.17 \mathrm{~V}$ (bottom) vs SCE were used to perform crossover studies. 


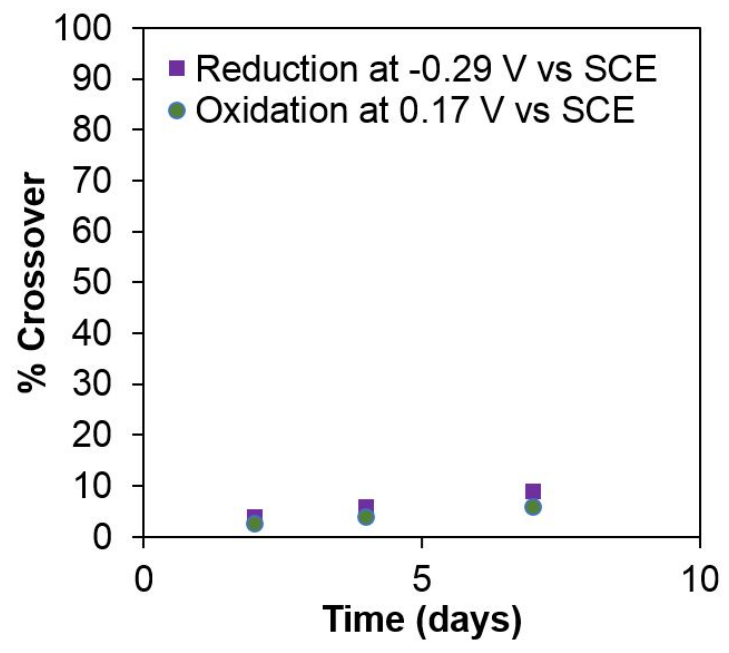

Figure S7. Crossover of analyte $\mathbf{2 b}$ over time. Purple squares are the \% crossover as measured from the reduction event at $-0.29 \mathrm{~V}$ vs SCE (from calibration curve in Figure $\mathrm{S} 13$ ) and teal circles are $\%$ crossover as measured from oxidation event at $0.17 \mathrm{~V}$ vs SCE.
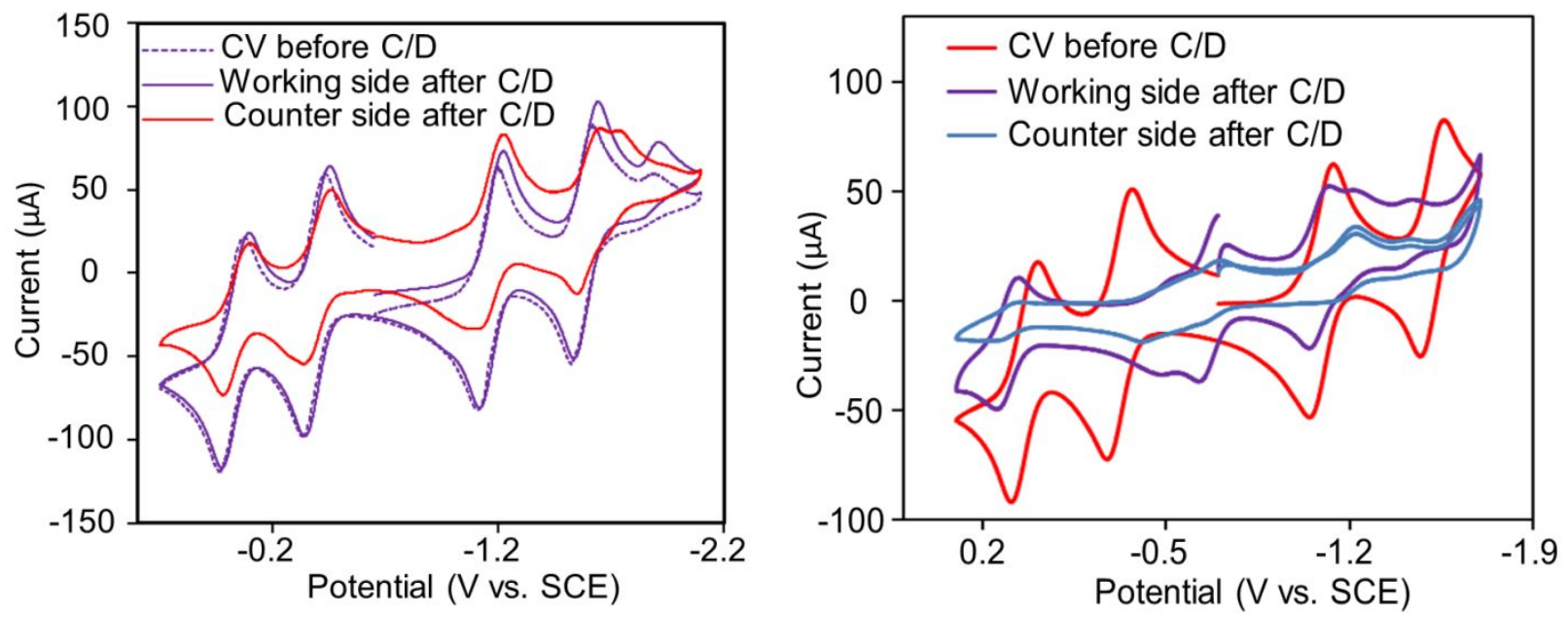

Figure S8. CV's of working (purple) and counter (red) compartments after (left) $73 \mathrm{~h}$ of charging and discharging of $\mathbf{2 b}$ in a symmetric H-cell using a glass frit separator and (right) after $450 \mathrm{~h}$. CV's were taken by removing an aliquot from the H-cell after C/D experiments (glassy carbon button working, $\mathrm{Pt}$ wire counter, $\mathrm{Ag} / \mathrm{AgNO}_{3}$ reference electrodes). 


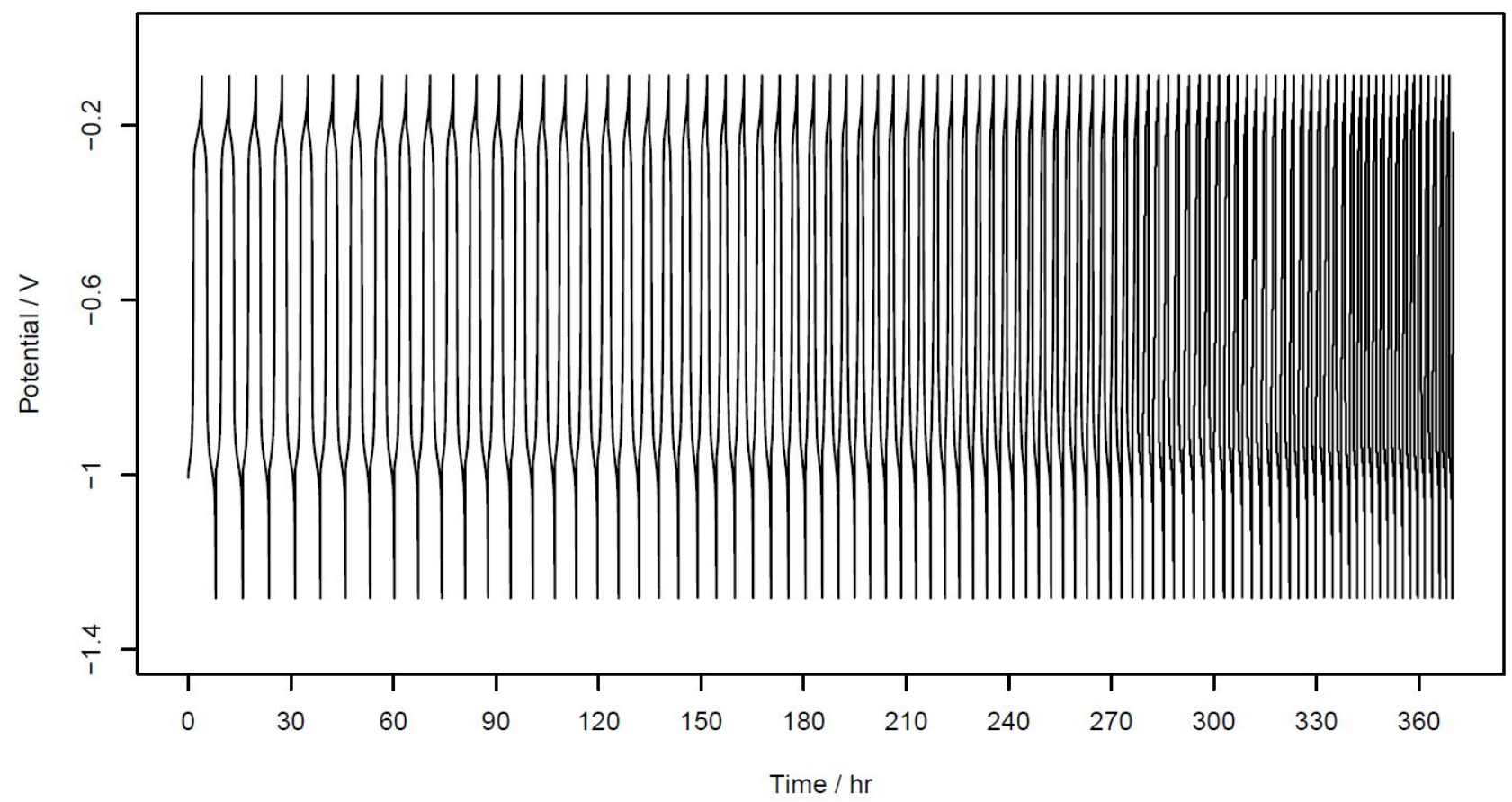

Figure S9. Extended cycling of $\mathbf{2 b}$ using a fine glass frit separator in a symmetric modified $\mathrm{H}-$ cell, with $0.2 \mathrm{~mA}$ charging and discharging currents.

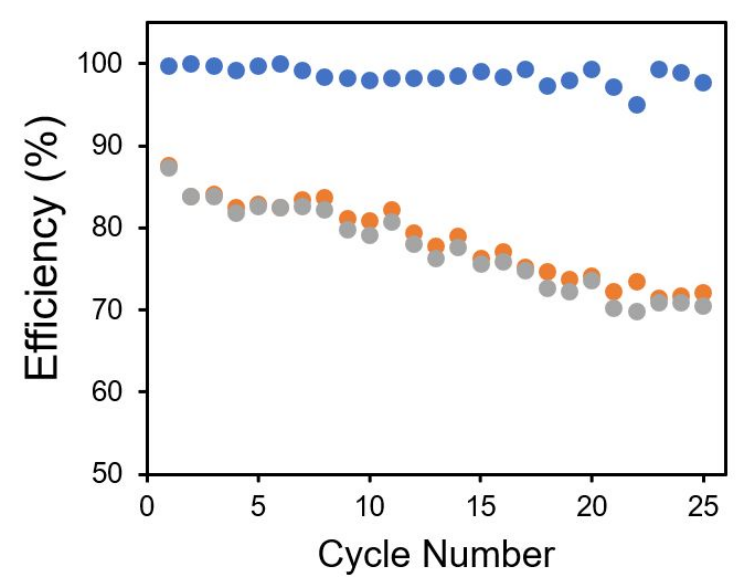

Figure S10. Voltaic (orange), coulombic (blue) and overall (gray) energy efficiency over the first $25 \mathrm{C} / \mathrm{D}$ cycles of $\mathbf{2 b}$ in a symmetric $\mathrm{H}$-cell separated by a fine glass frit. 

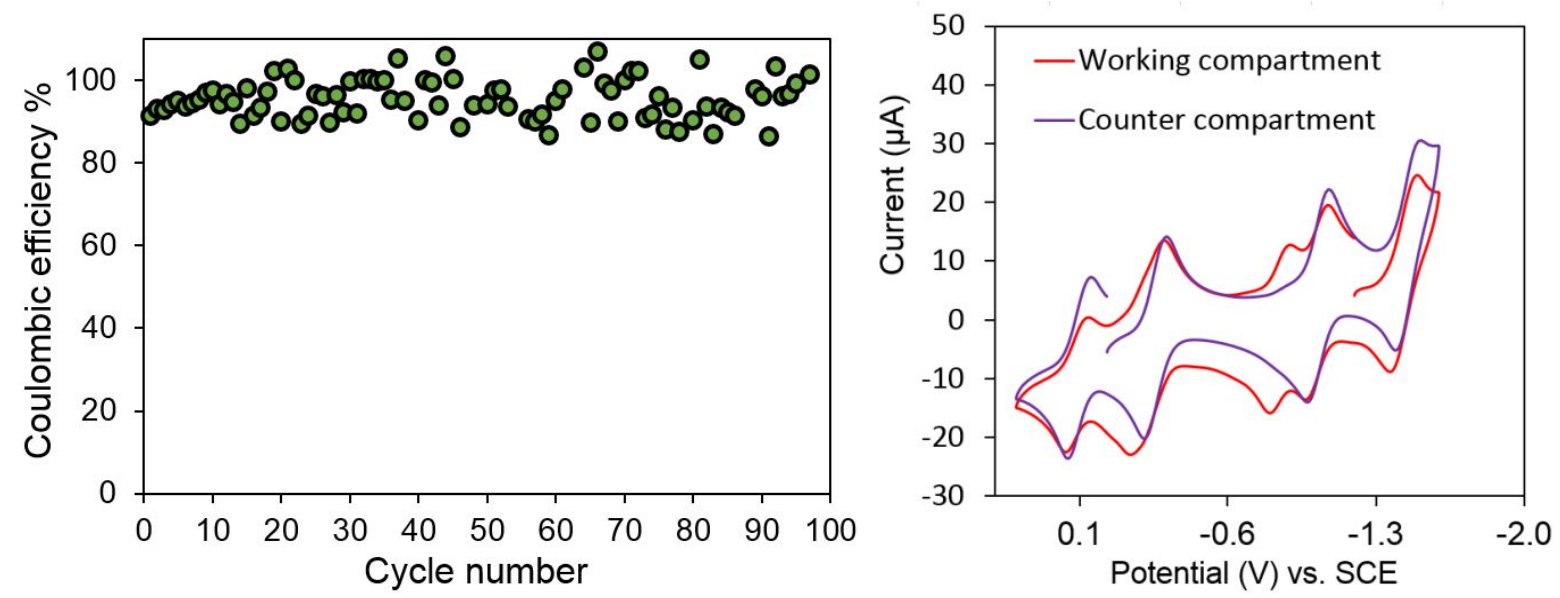

Figure S11. (left) Coulombic efficiency of $100 \mathrm{C} / \mathrm{D}$ cycles using an anion-exchange membrane separator. (right) CV's of working (purple) and counter (red) compartments after 100 charging and discharging cycles using an anion exchange membrane.

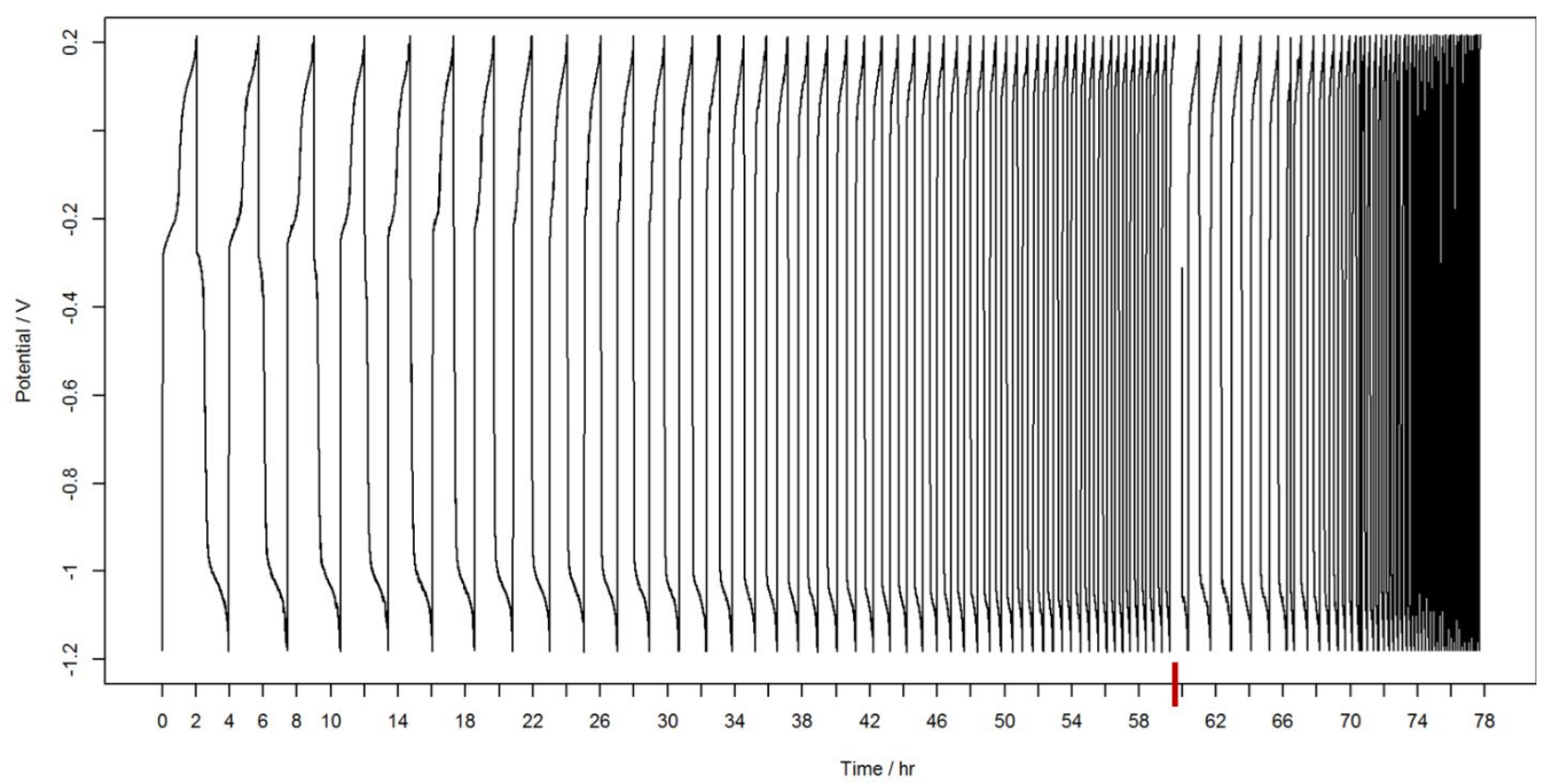

Figure S12. 100 galvanostatic charging and discharging cycles using an anion-exchange membrane in a symmetric modified $\mathrm{H}$-cell. Red line designates a pause in the experiment; here, CV's were taken to check the stability of the analyte. 

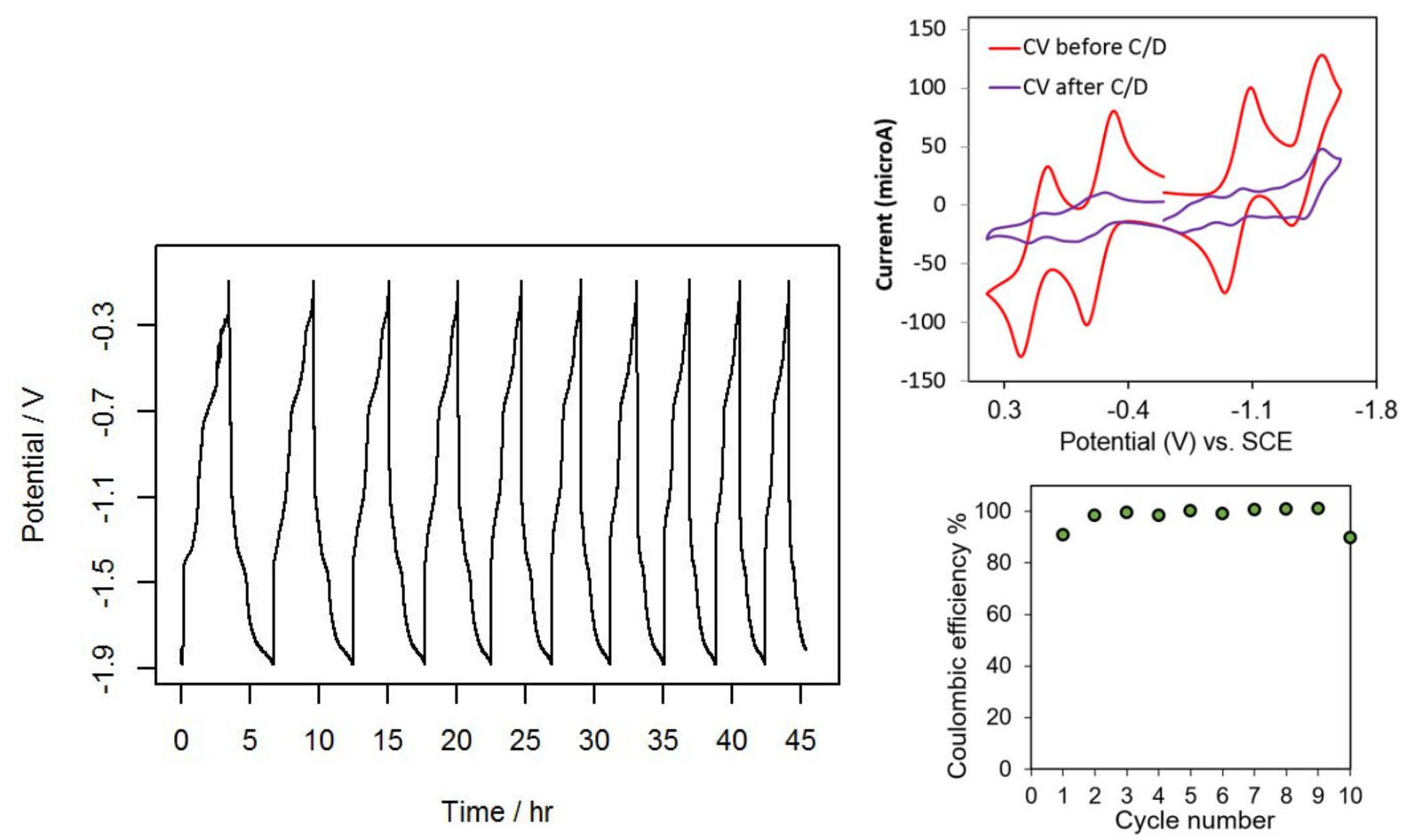

Figure S13. Cycling using $\mathbf{2 b}$ as an anolyte for an asymmetric battery cell using an anion-exchange membrane separator (left); (right top) CV's of working compartment of asymmetric H-cell battery, after 10 cycles; Coulombic efficiency of each cycle (bottom right). GC button electrode.
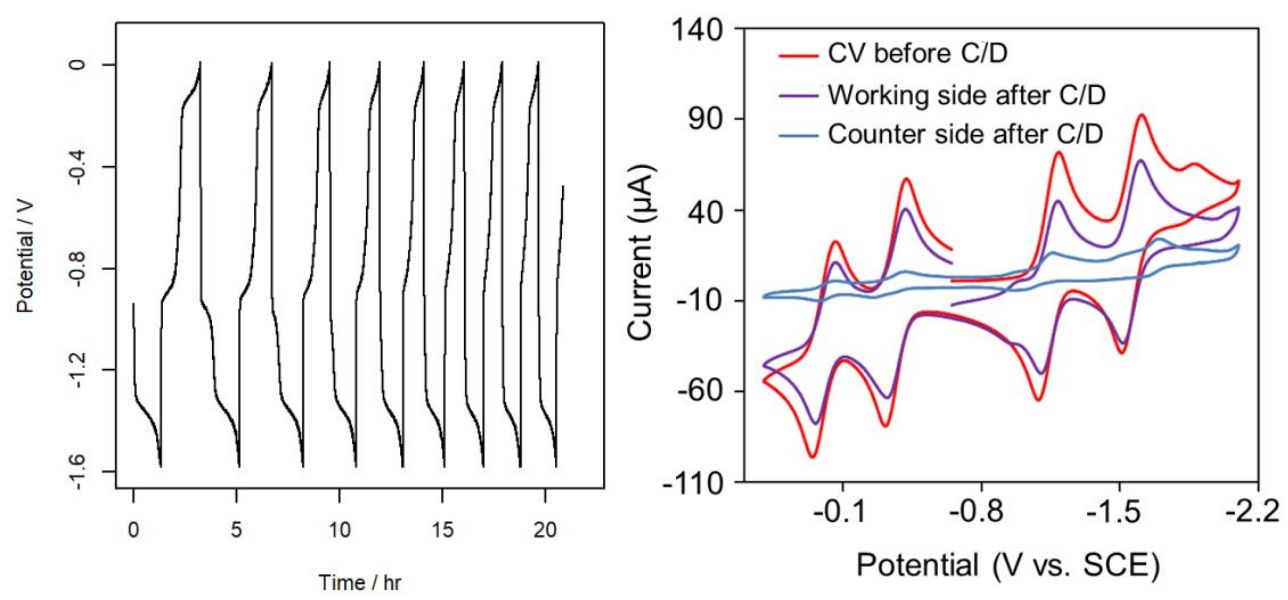

Figure S14. C/D (left) and CV's (right) of asymmetric H-cell battery with glass frit separator, with $V_{\text {cell }}=1.6 \mathrm{~V}$ after $<9$ cycles over $21 \mathrm{~h}$. While the compound appears highly stable in the working side, crossover was prominent in the counter compartment (blue trace, right). 


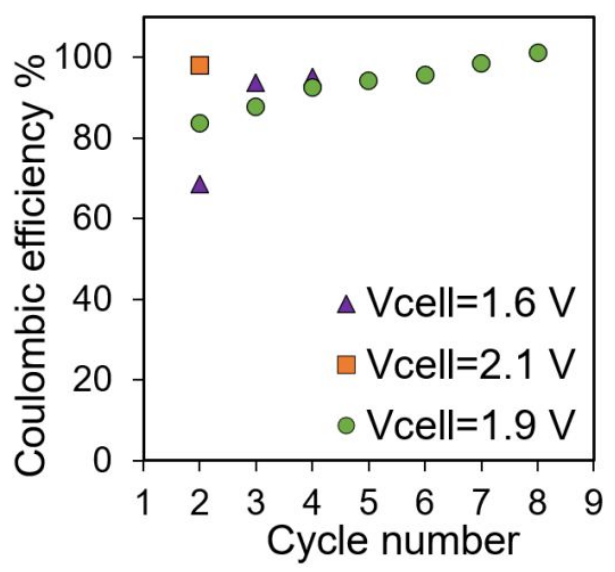

Figure S15. Coulombic efficiency of each $\mathrm{C} / \mathrm{D}$ cycle with asymmetric H-cell battery with glass frit separator, with $V_{\text {cell }}=1.6 \mathrm{~V}$ (orange square), $V_{\text {cell }}=1.9 \mathrm{~V}$ (purple triangle) and $V_{\text {cell }}=2.1 \mathrm{~V}$ (green circle) over $21 \mathrm{~h}$.
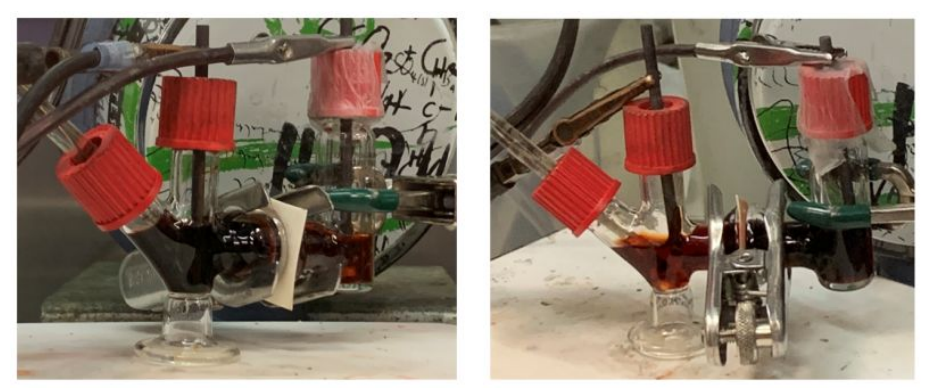

Figure S16. $\mathrm{H}-\mathrm{Cell}$ with anion-exchange membrane separator, $\mathrm{Ag} / \mathrm{AgNO} \mathrm{N}_{3}$ reference electrode (left side port), graphite rod working and counter electrodes. Darkening (left) of working electrode compartment solution observed upon reaching low potential cutoff and lightening (right) of solution observed upon reaching high potential cutoff.

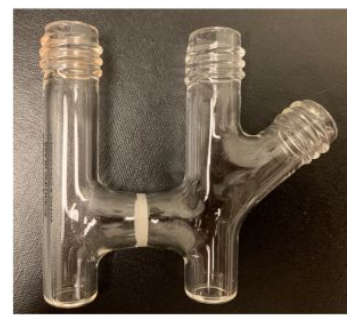

Figure S17. H-Cell with glass frit separator, from Adams and Chittenden Scientific Glass. ${ }^{5}$ 


\section{References}

${ }^{1}$ Connelly, N. G.; Geiger, W. E., Chemical Redox Agents for Organometallic Chemistry. Chem. Rev. 1996, 96 (2), 877-910.

2 (a) SMART Software Users Guide, Version 5.1, Bruker Analytical X-Ray Systems, Inc.; Madison, WI 1999. (b) SAINT Software Users Guide, Version 7.0, Bruker Analytical X-Ray Systems, Inc.; Madison, WI 1999. (c) Sheldrick, G. M. SADABS, Version 2.03, Bruker Analytical X-Ray Systems, Inc.; Madison, WI 2000. (d) Sheldrick, G. M. SHELXTL Version 6.12, Bruker Analytical X-Ray Systems, Inc.; Madison, WI 1999. (e) International Tables for XRay Crystallography, 1992, Vol. C., Dordrecht: Kluwer Academic Publishers.

${ }^{3}$ Arnold, A.; Sherbow, T. J.; Sayler, R. I.; Britt, R. D.; Thompson, E. J.; Muñoz, M. T.; Fettinger, J. C.; Berben, L. A. Organic Electron Delocalization Modulated by Ligand Charge States in $\left[\mathrm{L}_{2} \mathrm{M}\right]^{\mathrm{n}-}$ Complexes of Group 13 Ions. J. Am. Chem. Soc., 2019, 141, 15792-15803.

${ }^{4}$ Lavagnini, I.; Antiochia, R.; Magno, F. An Extended Method for the Practical Evaluation of the Standard Rate Constant from Cyclic Voltammetric Data. Electroanalysis 2004, 16, 505-506.

${ }^{5}$ Adams \& Chittenden Scientific Glass. http://www.adamschittenden.com/ 